\title{
La hija del Boticario
}

\section{The apothecary's daughter}

\section{Leticia Villamil Navarrete. ${ }^{a}$}

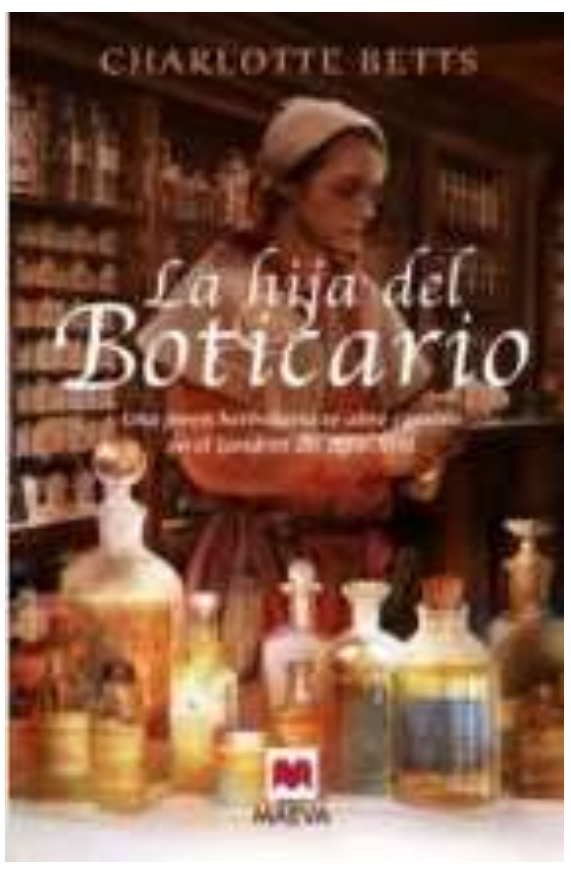

Cornelius es un boticario viudo que vive con su hija Susannah. Además de encargarse de llevar la casa y las cuentas de la botica, Susannah es gran admiradora del trabajo de su padre y le encanta ayudar a preparar los brebajes que a éste le encargan algunos médicos de la ciudad y los clientes. Poco a poco aprende a realizar las mezclas con las cantidades exactas a base de plantas como la lavanda, el regaliz o la trementina, entre muchas más y acaba convirtiéndose en una gran experta en remedios naturales, algo muy inusual en una mujer de aquella época. Su padre conoce a una joven viuda con hijos y se enamora completamente de ella, hasta el punto de contraer matrimonio. Y la vida de la joven boticaria cambia por completo: deja de ser la niña de los ojos de su papá, las interesantes lecturas y debates acerca de diversos temas que tienen entre ellos se quedan a un lado y durante una época, se convierte en una especie de Cenicienta que, además de ayudar a su padre en la botica, tiene que cuidar y mantener distraídos a sus incontrolables hermanastros. Por si fuera poco, su madrastra es insoportable y sus días cada vez se hacen menos llevaderos y complicados hasta que conoce a Henry Savage, un atractivo joven, amigo de la familia, que intenta convencerla de que está completamente enamorado de ella y le pide la mano. Susannah, a pesar de los miedos que tiene a contraer matrimonio y de las obligaciones que eso conlleva, sobre todo la procreación, sigue el consejo de su buena amiga y acaba aceptando la propuesta, dejando atrás la convulsa vida que ha llevado durante los meses anteriores. Pero pronto se da cuenta de que su marido es diferente, muy diferente a como ella había imaginado. La abandona con la 
excusa de que tiene negocios que atender, llega muy tarde a casa y por mucho que ella intenta "ser una buena esposa" él la rechaza. Tras algunos meses de matrimonio y ante la desaparición durante algunos días de Henry, a Susannah le llega una trágica noticia: su marido ha fallecido a causa de la peste, como muchos otros ciudadanos de Londres de esa época y su vida se viene completamente abajo al darse cuenta de que se ha quedado sola, sumida en las deudas que su marido ha dejado por todas partes y sin la dote que su padre había entregado a Henry. Momentos duros y difíciles que acaba lidiando con su astucia, su inteligencia y su pasión por la medicina natural, y que a pesar de la virulencia de la epidemia y de todos los avatares que van aconteciendo en una sociedad afectada también por otras enfermedades, su vida da un giro inesperado.

\section{Referencia}

Betts, C. (2015). La hija del Boticario. MAEVA. 